"This is the peer reviewed version of the following article:

Electrochemical and Resonance Raman Spectroscopic Studies of Water-Oxidizing RutheniumTerpyridyl-Bipyridyl Complexes, which has been published in final form at http://onlinelibrary.wiley.com/doi/10.1002/cssc.201601221/abstract

This article may be used for non-commercial purposes in accordance with Wiley Terms and Conditions for SelfArchiving."

\title{
Electrochemical and Resonance Raman Spectroscopic Studies of Water-Oxidizing Ruthenium-Terpyridyl-Bipyridyl Complexes
}

\author{
Anke Keidel, ${ }^{[a] \S}$ Isidoro López, ${ }^{[b] \S}$ Jana Staffa, ${ }^{[a]}$ Uwe Kuhlmann, ${ }^{[a]}$ Fernando Bozoglian, ${ }^{[b]}$ Carolina \\ Gimbert-Suriñach, ${ }^{[b]}$ Jordi Benet-Bucholz, ${ }^{[b]}$ Peter Hildebrandt, ${ }^{*[a]}$ and Antoni Llobet ${ }^{*[b][c]}$ \\ ${ }^{\S}$ Equal contribution to the work
}

\begin{abstract}
The irreversible conversion of single-site water oxidation catalysts (WOC) into the more rugged catalysts structurally related to $\left[(\operatorname{trpy})\left(5,5^{\prime}-\mathrm{X}_{2}-\text { bpy }\right) \mathrm{Ru}^{\mathrm{IV}}(\mu-\mathrm{O}) \mathrm{Ru}^{\mathrm{IV}}(\operatorname{trpy})(\mathrm{O})\left(\mathrm{H}_{2} \mathrm{O}\right)\right]^{4+}\left(\mathrm{X}=\mathrm{H}, \mathbf{1}-\mathrm{dn}^{4+} ; \mathrm{X}\right.$ $\left.=\mathrm{F}, \mathbf{2}-\mathbf{d n}^{4+}\right)$ represents a critical issue in developing active and durable WOC. In this work, the electrochemical and acid-base properties of $\mathbf{1}-\mathbf{d n}^{4+}$ and $\mathbf{2}-\mathbf{d n}^{4+}$ were evaluated. In-situ resonance Raman spectroscopy was employed to characterize species formed upon stoichiometric oxidation of single-site catalysts demonstrating the formation of high oxidation states mononuclear $\mathrm{Ru}=\mathrm{O}$ and $\mathrm{RuO}$ O complexes. Under turnover conditions, the dinuclear intermediates, 1-dn $\mathbf{n}^{4+}$ and $\mathbf{2 -} \mathbf{d n}^{4+}$, as well as the previously proposed $\left[\mathrm{Ru}^{\mathrm{VI}}(\operatorname{trpy})(\mathrm{O})_{2}\left(\mathrm{H}_{2} \mathrm{O}\right)\right]^{2+}$ complex $\left(3^{2+}\right)$ are formed. $3^{2+}$ is a pivotal intermediate that provides access to the formation of dinuclear species. Single crystal $\mathrm{X}$-ray diffraction analysis of the isolated complex $\left[R u^{\mathrm{IV}}(\mathrm{O})(\mathrm{trpy})\left(5,5^{\prime}-\mathrm{F}_{2} \text {-bpy) }\right]^{2+}\right.$ reveals a clear elongation of the Ru-N bond located in the trans position to the oxo group, documenting the weakness of this bond which promotes the release of the bpy ligand and the subsequent formation of $3^{2+}$.
\end{abstract}

\section{Introduction}

\author{
[a] A. Keidel, J. Staffa, Dr. U. Kuhlmann, Prof. Dr. P. Hildebrandt \\ Institut für Chemie Department \\ Technische Universität Berlin \\ Sekr. PC14, Straße des 17. Juni 135 \\ D-10623 Berlin 1 \\ E-mail: Hildebrandt@chem.tu-berlin.de \\ [b] Dr. I. López, Dr. F. Bozoglian, Dr. C. Gimbert-Suriñach, Dr. J. Benet- \\ Buchholz, Prof. Dr. A. Llobet \\ Institute of Chemical Research of Catalonia (ICIQ) \\ Barcelona Institute of Science and Technology (BIST) \\ Av. Països Catalans, 16, 43007, Tarragona, Spain \\ E-mail: allobet@iciq.cat \\ [b] Prof. A. Llobet \\ Departament de Química \\ Universitat Autònoma de Barcelona \\ Cerdanyola del Vallès, 08193 Barcelona, Spain
}

Supporting information for this article is given via a link at the end of the document
The generation of molecular oxygen from water is one of the key challenges in contemporary chemistry and it has been in the focus of researchers for many decades. The research in this field has strongly profited from the development of catalytically competent well-defined transition metal complexes since they allow for profound mechanistic studies. Single-site water oxidizing catalysts (WOC) have gained strong interest, starting with the synthesis and characterization of the first active mononuclear ruthenium complex by Thummel et al. ${ }^{[1]}$ Subsequent mechanistic studies by Meyer et al..$^{[2-4]}$ have led to a proposal of the catalytic pathway in which the key O-O bond formation step results from a water nucleophilic attack on the $\mathrm{Ru}^{\mathrm{v}}=\mathrm{O}$ unit (Figure 1). It is assumed that this mechanism holds for a variety of mononuclear $\mathrm{Ru}$ catalysts from $\left[\mathrm{Ru} \text { (trpy)(bpy) }\left(\mathrm{H}_{2} \mathrm{O}\right)\right]^{2+}\left(\mathbf{1}^{2+}\right)$ (where trpy is $2,2^{\prime}: 6^{\prime}, 2^{\prime \prime}$-terpyridine and bpy is $2,2^{\prime}$-bipyridine) analogues ${ }^{[5,6]}$ to single site $\mathrm{Ru}$ polyoxometalates, ${ }^{[7]}$ and may also provide a description of molecular catalysts involving iridium ${ }^{[8]}$ and other first-row transition metals. ${ }^{[9,10]}$ Substantial efforts have been made to identify the proposed metal peroxido and hydroperoxido intermediates and possible side products via EPR, UV-vis and vibrational spectroscopy. However, a comprehensive characterization of all intermediates and an unambiguous confirmation of the mechanism has not been achieved up to now. ${ }^{[3,11]}$ Additional information can be derived from kinetic analyses, extended to compounds with modifications in the ligand framework. For instance, Fujita et al. ${ }^{[12]}$ and Yagi et al. ${ }^{[13]}$ have examined the effect of a pendant base on catalytic water oxidation. They found a drastic decrease of the activity when the base is placed next to the aquo ligand while the stereoisomeric complex with a distant pendant base displays an improved catalytic performance compared to $\mathbf{1}^{2+}$. We have also studied the remarkable effect exerted by a proximal fluorine atom on the Ru-aqua group of the complex. ${ }^{[6]}$ The modified bipyridine ligand forms a hydrogen bond with the active site which lowers the activity. It is further worth mentioning that 2,2'-bipyridine $\mathrm{N}, \mathrm{N}$ dioxide has been observed as the main deactivation product after catalysis with $\mathbf{1}^{2+}$ and using a large excess of $\left[\left(\mathrm{NH}_{4}\right)_{2} \mathrm{Ce}\left(\mathrm{NO}_{3}\right)_{6}\right]\left(\mathrm{Ce}^{\mathrm{IV}}\right.$ hereafter $)$ as sacrificial oxidant, ${ }^{[14]}$ which points to the dissociation of the bpy ligand as an important pathway of catalyst degradation. Finally Sakai et al. found kinetic 
"This is the peer reviewed version of the following article:

Electrochemical and Resonance Raman Spectroscopic Studies of Water-Oxidizing Ruthenium-

Terpyridyl-Bipyridyl Complexes, which has been published in final form at http://onlinelibrary.wiley.com/doi/10.1002/cssc.201601221/abstract

This article may be used for non-commercial purposes in accordance with Wiley Terms and Conditions for SelfArchiving."

evidence that the $\mathrm{Ce}(\mathrm{IV})$ might have a role in the O-O bond formation pathway pointing out to a different reaction mechanism. $^{[15]}$

Recently, our group has demonstrated that $\mathbf{1}^{2+}$ and the structurally related complex $\left[\mathrm{Ru}(\operatorname{trpy})\left(5,5^{\prime}-\mathrm{F}_{2}-\mathrm{bpy}\right)\left(\mathrm{H}_{2} \mathrm{O}\right)\right]^{2+}$ (where $5,5^{\prime}-\mathrm{F}_{2}$-Bpy is $5,5^{\prime}$-difluoro-2,2'-bipyridine, $\mathbf{2}^{\mathbf{2 +}}$ ) are partly converted into the new oxidatively rugged and active dinuclear catalysts $\left[(\operatorname{trpy})\left(5,5^{\prime}-\mathrm{X}_{2} \text {-bpy)Ru } u^{\mathrm{IV}}(\mu-\mathrm{O}) \mathrm{Ru}^{\mathrm{IV}}(\operatorname{trpy})(\mathrm{O})\left(\mathrm{H}_{2} \mathrm{O}\right)\right]^{4+}(\mathrm{X}=\right.$ $\mathrm{H}, \mathbf{1}-\mathbf{d n}^{4+} ; \mathrm{X}=\mathrm{F}, \mathbf{2}-\mathbf{d n}^{4+}$ ) under catalytic conditions (Figure 1). ${ }^{[16]}$ This finding provided novel insight into the reactivity of so-called single-site water oxidation catalysts and did not only question the original mechanistic description of these catalysts but also disclosed the true molecular nature of the species responsible for the catalytic reaction. In this respect, two catalytic cycles run concurrently, one involving mononuclear complexes and the other one dinuclear complexes (Figure 1). The mononuclear species are irreversibly converted into the dinuclear ones via $\left[\mathrm{Ru}^{\mathrm{VI}}(\operatorname{trpy})(\mathrm{O})_{2}\left(\mathrm{H}_{2} \mathrm{O}\right)\right]^{2+}\left(3^{2+}\right)$ that acts as a gate between the two mechanistic cycles (Figure 1).

In this work, we have studied the spectroscopic and

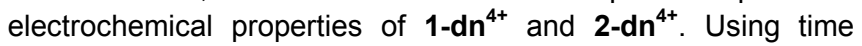
resolved resonance Raman (RR) spectroscopy, we analysed the reactions of $\mathbf{1}^{2+}$ and $\mathbf{2}^{2+}$ with $\mathrm{Ce}^{\mathrm{IV}}$ under stoichiometric and turnover conditions to identify intermediates of the catalytic cycle. The results are discussed on the background of the previously proposed mechanism. ${ }^{[16]}$
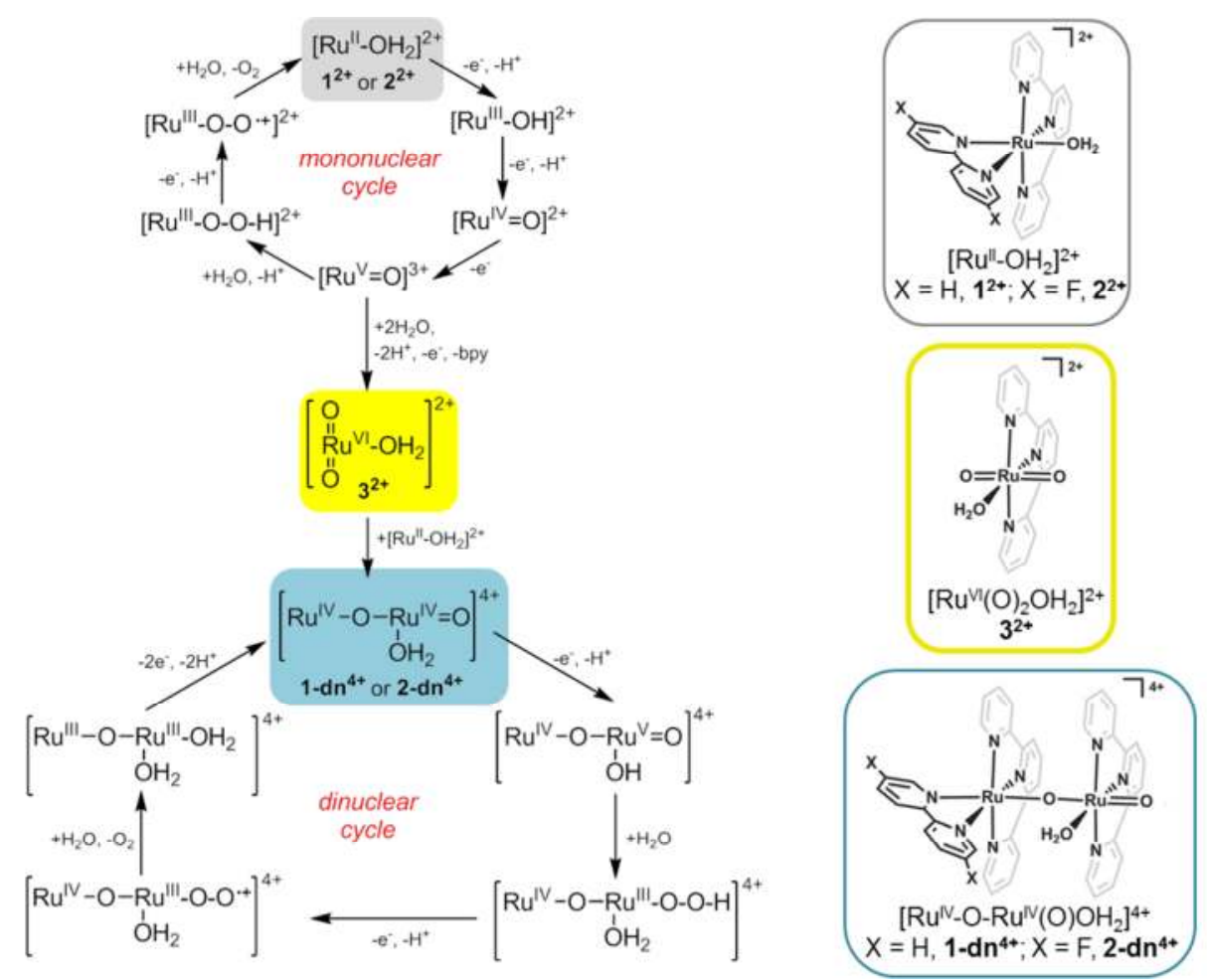

Figure 1. Left, Proposed reaction scheme for the water oxidation mechanisms by the monomeric Rul complexes $\mathbf{1}^{2+}, \mathbf{2}^{2+}$ and dinuclear $\mathrm{Ru} \mathrm{u}^{\mathrm{IV}} \mathrm{Ru} \mathrm{IV}^{\mathrm{IV}}$ complexes 1 $\mathbf{d n}^{4+}$ and $2-\mathbf{d n}^{4+}$, the two cycles are connected through the intermediate $3^{2+}$ according to previous results. ${ }^{[16]}$ Polypyridyl ligands are omitted for clarity. Right, Structural formulas of $\mathbf{1}^{2+}, 2^{2+}, 3^{2+}, 1-\mathrm{dn}^{4+}$ and $2-\mathrm{dn}^{4+}$.

\section{Results and Discussion}

1.Synthesis and electrochemical properties of dinuclear complexes

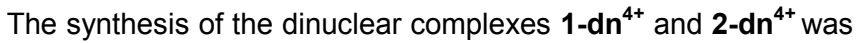
described previously. ${ }^{[16]}$ Briefly, both compounds were prepared by reacting equimolar amounts of trans- $\left[\mathrm{Ru}^{\mathrm{Vl}}(\operatorname{trpy})(\mathrm{O})_{2}\left(\mathrm{H}_{2} \mathrm{O}\right)\right]^{2+}$ $\left(3^{2+}\right)$ and the corresponding mononuclear complex, $\mathbf{1}^{2+}$ and $2^{2+}$, in the presence of $\mathrm{Ce}^{\mathrm{IV}}$ for two or three days. After filtration, the 
"This is the peer reviewed version of the following article:

Electrochemical and Resonance Raman Spectroscopic Studies of Water-Oxidizing Ruthenium-

Terpyridyl-Bipyridyl Complexes, which has been published in final form at http://onlinelibrary.wiley.com/doi/10.1002/cssc.201601221/abstract

This article may be used for non-commercial purposes in accordance with Wiley Terms and Conditions for SelfArchiving."

$E^{0}(\mathrm{IV}, \mathrm{IV} / \mathrm{III}, \mathrm{III})$. Thus, the low value of the potential for the III,III/II,II couple explains why the oxo-bridged dinuclear complexes are usually isolated in high oxidation states, typically III,III.

The standard potentials for the IV,IV/III,III couple in 1-dn ${ }^{4+}$ and 2- $\mathrm{dn}^{4+}$ are slightly lower than the potentials for the IV/III or IV/II couples of the related mononuclear complexes $\mathbf{1}^{2+}$ and $\mathbf{2}^{2+}$ (entry 1 vs. 6 and entry 2 vs. 7). However, the onset potential for the electrocatalytic current is quite similar.

The formal potentials for the reduction of $\mathbf{1 - \mathbf { d n } ^ { 4 + }}$ depend on the $\mathrm{pH}$ due to the acid-base properties of the different oxidation states (Eq. 2 and 3). This dependence was studied over a broad $\mathrm{pH}$ range and is shown in the Pourbaix diagram depicted in
Figure 3. The figure contains the $E_{1 / 2}-\mathrm{pH}$ values obtained from CV experiments.

The straight line corresponding to the IV,IV/III,III couple displays a constant slope of $59 \mathrm{mV} / \mathrm{pH}$ unit in the $\mathrm{pH}$ range studied here $(0-9)$. This value is consistent with a two-electron reduction with the addition of two protons. Regarding the couple III,III/II,II, a slope of approximately $30 \mathrm{mV} / \mathrm{pH}$ unit is observed in agreement with a two-electron reduction accompanied by the addition of one proton. Because both couples exhibit a constant slope in the entire $\mathrm{pH}$ range, spectrophotometric determinations of the $\mathrm{pKa}$ values for the oxidation states IV,IV and III,III were carried out (Figure 4).

Table 1. Summary of reduction potentials ( $\mathrm{V}$ vs. SSCE) for various dinuclear and mononuclear complexes at $\mathrm{pH} 1$.

\begin{tabular}{|c|c|c|c|c|c|c|c|c|}
\hline \multicolumn{9}{|c|}{ Dinuclear complexes } \\
\hline \multirow[b]{2}{*}{ Entry } & \multirow[b]{2}{*}{ Complex $^{[a]}$} & \multicolumn{5}{|c|}{$E^{0}$} & \multirow[b]{2}{*}{$E_{\text {onset }^{[b]}}$} & \multirow[b]{2}{*}{ Ref. } \\
\hline & & & III,IV/III,III & \multicolumn{2}{|r|}{ IV,IV/III,III } & III,III/II,II & & \\
\hline 1 & $1-\mathrm{dn}^{4+}$ & & --- & \multicolumn{2}{|r|}{$0.78^{[\mathrm{d}]}$} & $0.18^{[\mathrm{d}, \mathrm{e}]}$ & 1.45 & $\mathrm{Tw}^{[\mathrm{c}]}$ \\
\hline 2 & $2-\mathrm{dn}^{4+}$ & & --- & \multicolumn{2}{|r|}{$0.80^{[\mathrm{d}]}$} & $0.21^{[\mathrm{d}, \mathrm{e}]}$ & 1.47 & $\mathrm{Tw}^{[\mathrm{cc}]}$ \\
\hline 3 & $\left\{\left[\mathrm{Ru}(\mathrm{bpy})_{2}\left(\mathrm{H}_{2} \mathrm{O}\right)\right]_{2}(\mu-\mathrm{O})\right\}^{4+}$ & & 0.79 & \multicolumn{2}{|r|}{$>1.17^{[f]}$} & $<0.06^{[g]}$ & --- & 19 \\
\hline 4 & $\left\{\left[\mathrm{Ru}(\operatorname{trpy})\left(\mathrm{H}_{2} \mathrm{O}\right)\right]_{2}(\mu \text {-bpp })\right\}^{3+}$ & & 0.88 & \multicolumn{2}{|r|}{$0.98^{[\mathrm{h}]}$} & 0.62 & 1.30 & 25,26 \\
\hline 5 & $\left\{[\operatorname{Ru}(\operatorname{trpy})(\mathrm{bpy})]_{2}(\mu-\mathrm{O})\right\}^{4+}$ & & 1.08 & \multicolumn{2}{|r|}{---} & $0.21^{[\mathrm{d}, \mathrm{e}]}$ & -- & 27 \\
\hline \multicolumn{9}{|c|}{ Mononuclear complexes } \\
\hline \multirow[b]{2}{*}{ Entry } & & \multicolumn{5}{|c|}{$E^{0}$} & \multirow[b]{2}{*}{$E_{\text {onset }^{[b]}}$} & \multirow[b]{2}{*}{ Ref. } \\
\hline & Complex & III/II & & IV/III & IV/II & V/IV & & \\
\hline 6 & $1^{2+}$ & 0.82 & & 0.98 & 0.90 & 1.62 & 1.45 & 6,24 \\
\hline 7 & $2^{2+}$ & --- & & --- & $0.87^{[\mathrm{d}]}$ & 1.68 & 1.48 & 6 \\
\hline 8 & $3^{2+}$ & 0.47 & & 0.87 & 0.67 & $>1.03^{[i]}$ & --- & 22 \\
\hline
\end{tabular}

[a] Ligand abbreviation: bpp = bis(2-pyridyl)-3,5-pyrazolate. [b] Potential refers to the value where electrocatalysis starts. [c] Tw: this work. [d] Two electron process. [e] Chemically irreversible process; the indicated potential corresponds to $E_{\mathrm{p}, \mathrm{c}}-0.015 \mathrm{~V}$. [f] The oxidation state IV,IV is unstable with respect to disproportion. Thus, $E^{0}$ is estimated considering that $E^{0}(\mathrm{IV}, \mathrm{IV} / \mathrm{III}, \mathrm{IV})>E^{0}(\mathrm{~V}, \mathrm{~V} / \mathrm{III}, \mathrm{IV})$ where the latter is $1.22 \mathrm{~V}$. [g] The oxidation state II,III undergoes oxo bridge cleavage on the time scale of the $\mathrm{CV}$; however, $E^{0}(\mathrm{III}, \mathrm{III} / \mathrm{II}, \mathrm{II})$ cannot be lower than $E^{0}(\mathrm{III}, \mathrm{III} / \mathrm{II}, \mathrm{III})$. [h] The wave associated with the IV,IV/III,IV couple is electrochemically irreversible; thus, $E_{1 / 2}$ was estimated taking $E_{\mathrm{p}, \mathrm{a}}-0.03 \mathrm{~V}$. [i] The oxidation state $\mathrm{V}$ is unstable with respect to disproportion; thus this $E^{0}$ must be larger than $E^{0}(\mathrm{VI} / \mathrm{IV})=1.03 \mathrm{~V}$. 
"This is the peer reviewed version of the following article:

Electrochemical and Resonance Raman Spectroscopic Studies of Water-Oxidizing Ruthenium-

Terpyridyl-Bipyridyl Complexes, which has been published in final form at http://onlinelibrary.wiley.com/doi/10.1002/cssc.201601221/abstract

This article may be used for non-commercial purposes in accordance with Wiley Terms and Conditions for SelfArchiving."

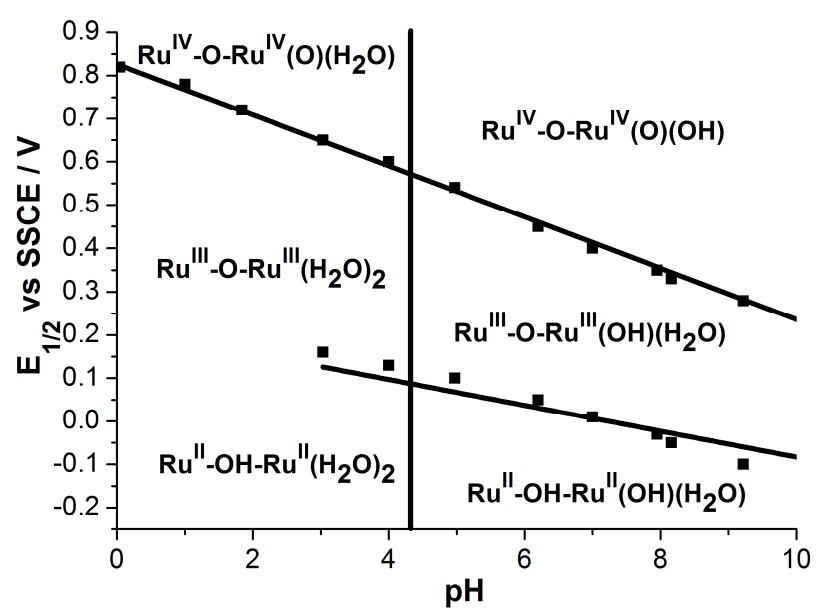

Figure 3. Pourbaix diagram for $1-\mathbf{d n}^{4+}$. The potential-pH regions where the various oxidation states are the dominant forms are indicated. The vertical line represents the $\mathrm{pK}_{\mathrm{a}}$ values obtained by spectrophotometric titrations. $\mathrm{E}_{1 / 2}$ values were obtained by $\mathrm{CV}$ using a scan rate of $100 \mathrm{mV} \mathrm{cm}^{-1}$.

The acid-base titration of IV,IV showed distinct isosbestic points at $363,415,481$ and $707 \mathrm{~nm}$ and the $\mathrm{pK}_{\mathrm{a}}(\mathrm{IV}, \mathrm{IV})$ was calculated to be 4.4. The acid-base titration of the III,III derivative was determined using a solution of the complex obtained by coulometric reduction of the initial IV,IV form yielding a $\mathrm{pK}_{\mathrm{a}}(\mathrm{III}, \mathrm{III})$ of 4.3. In this case, the UV-Vis spectra show more subtle changes as it has been previously observed in the oxidation state III,III of the blue dimer. ${ }^{[18]}$ The close similarity between both $\mathrm{pK}_{\mathrm{a}}$ values explains why the slopes of the Pourbaix diagram for the two redox couples remain unmodified in the entire $\mathrm{pH}$ range. Deprotonation of IV,IV would result in a change of the slope for the redox IV,IV/III,III couple from $-59 \mathrm{mV} / \mathrm{pH}$ unit $\left(2 \mathrm{e}^{-/} / 2 \mathrm{H}^{+}\right.$ exchanged) to $-29 \mathrm{mV} / \mathrm{pH}$ unit $\left(2 \mathrm{e}^{-} / 1 \mathrm{H}^{+}\right.$exchanged) but deprotonation of $\mathrm{III}, \mathrm{III}$ at near the same $\mathrm{pH}$ affords again an exchange of 2 protons in the couple. Instability of $1-\mathbf{d n}^{4+}$ above $\mathrm{pH} 9.50$, probably because of dimerization reactions, prevents us from obtaining reliable measurements at basic $\mathrm{pHs}$.

The $\mathrm{pK}_{\mathrm{a}}$ for the oxidation state IV,IV of $\mathbf{2 - \mathbf { d n } ^ { 4 + }}$ was also determined spectrophotometrically in order to gain insight into the influence of the bpy ligand on the acid-base properties of the dinuclear complexes (Figure S2). The calculated $\mathrm{pK}_{\mathrm{a}}(4.0)$ is lower than that found for $1-\mathbf{d n}^{4+}$ as expected from the electronwithdrawing effect of the fluorine substituents in the bpy ligand. The same behavior has been reported for the mononuclear parent complexes $\mathbf{1}^{2+}$ and $\mathbf{2}^{2+}{ }^{[6]}$ However, the effect is smaller in the dinuclear complexes because the bpy ligand has a weaker influence on the electronic structure of the complex as evidenced by the standard potentials (Table 1) and the UV-vis spectra (Figure S3 and Table S1).

The $\mathrm{pK}_{\mathrm{a}}$ value associated with the oxidation state II,II must be similar to that of the III,III state to account for the constant slope of this couple for the same reasons outlined above for IV,IV/III,III. However, we could not determine this quantity due to the previously discussed instability of this oxidation state with respect to oxo bridge cleavage. The release of the proton is ascribed to one of the aquo ligands rather than from the hydroxyl group, in line with conclusions drawn from studies of structurally related complexes. ${ }^{[17]}$
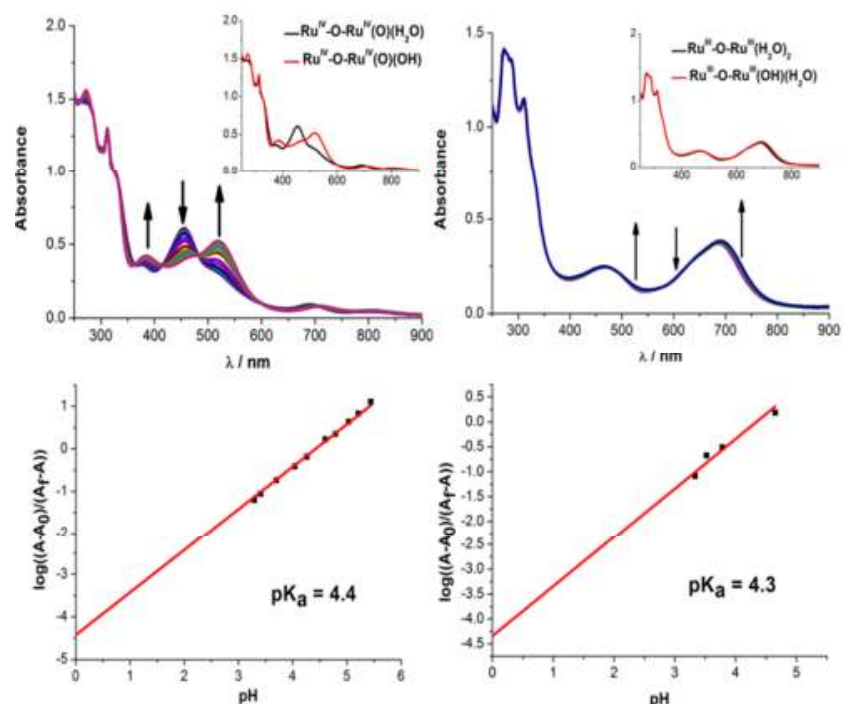

Figure 4. Top, Acid-base spectrophotometric titration of the oxidation state IV,IV (left) and III,III (right) of 1-dn ${ }^{4+}$ after consecutive additions of $1-5 \mu \mathrm{L}$ of $6.16 \mathrm{M} \mathrm{NaOH}$ to a $25 \mu \mathrm{M}$ solution of the complex in $0.1 \mathrm{M} \mathrm{H}_{3} \mathrm{PO}_{4} / \mathrm{NaH}_{2} \mathrm{PO}_{4}$ buffer at $\mathrm{pH}$ 2.15. $\mathrm{pH}$ changes for the titration of IV,IV: $2.32,2.52,2.78,3.29$, $3.41,3.70,4.04,4.26,4.60,4.79,5.03,5.21,5.44,5.73$ and 5.95. $\mathrm{pH}$ changes for the titration of III,III: $2.94,3.33,3.52,3.78,4.65$ and 5.22. Bottom, Calculation of the $\mathrm{pK}_{\mathrm{a}}$ value of the oxidation state IV, IV from the absorbance at $519 \mathrm{~nm}$ (left) and of the oxidation state III,III from the absorbance at $727 \mathrm{~nm}$ (right).

The interpretation of the Pourbaix diagram (Figure 3 ) is supported by the RR spectra of the oxidation states IV,IV and III,III (Figure 5). The spectrum of IV,IV, obtained with $514 \mathrm{~nm}$ laser excitation, is dominated by a strong band at $803 \mathrm{~cm}^{-1}$. In our previous work, this band was assigned to a mode including the stretching of the terminal $\mathrm{Ru}=\mathrm{O}$ bond, consistent with the ca. $40 \mathrm{~cm}^{-1}{ }^{18} \mathrm{O} /{ }^{16} \mathrm{O}$ isotopic shift. ${ }^{[16]} \mathrm{A}$ closer inspection reveals an additional weak band on the high-frequency side $\left(833 \mathrm{~cm}^{-1}\right)$ which also falls into the region expected for $\mathrm{Ru}=\mathrm{O}$ stretching. Upon $413 \mathrm{~nm}$ laser excitation, this latter band is preferentially 
"This is the peer reviewed version of the following article:

\section{Electrochemical and Resonance Raman Spectroscopic Studies of Water-Oxidizing Ruthenium-}

Terpyridyl-Bipyridyl Complexes, which has been published in final form at http://onlinelibrary.wiley.com/doi/10.1002/cssc.201601221/abstract

This article may be used for non-commercial purposes in accordance with Wiley Terms and Conditions for SelfArchiving."

enhanced compared to the $803 \mathrm{~cm}^{-1}$ band. Thus, we conclude that the $\mathrm{Ru}=\mathrm{O}$ and $\mathrm{Ru}-\mathrm{O}-\mathrm{Ru}$ stretching coordinates are strongly coupled, giving rise to two closely spaced modes at 803 and 833 $\mathrm{cm}^{-1}$ with different excitation profiles. Conversely, no ${ }^{18} \mathrm{O} /{ }^{16} \mathrm{O}-$ sensitive bands were observed in the region between 350 and $400 \mathrm{~cm}^{-1}$. Thus, the RR spectroscopic signature of the $\mathrm{Ru}=\mathrm{O}$ and Ru-O-Ru containing modes is quite different in the IV,IV state of $1-\mathbf{d n}^{4+}$ as compared to the corresponding ruthenium "blue dimer" species which displays "pure" (symmetric) Ru-O-Ru and $\mathrm{Ru}=\mathrm{O}$ stretching modes at ca. 369 and $818 \mathrm{~cm}^{-1}$ respectively, in its formal V,IV oxidation state. ${ }^{[28,29]}$

Upon reduction of the IV,IV form of $1-\mathbf{d n}^{4+}$ to the III,III state by addition of 2 equivalents of Mohr's salt, $\left(\mathrm{NH}_{4}\right)_{2} \mathrm{Fe}\left(\mathrm{SO}_{4}\right)_{2}$, the RR intensities of the bands at 803 and $833 \mathrm{~cm}^{-1}$ are strongly decreased (Figure $5 \mathrm{C}$ ) consistent with the lack of a $\mathrm{Ru}=\mathrm{O}$ function as concluded from the Pourbaix diagram (Figure 3).

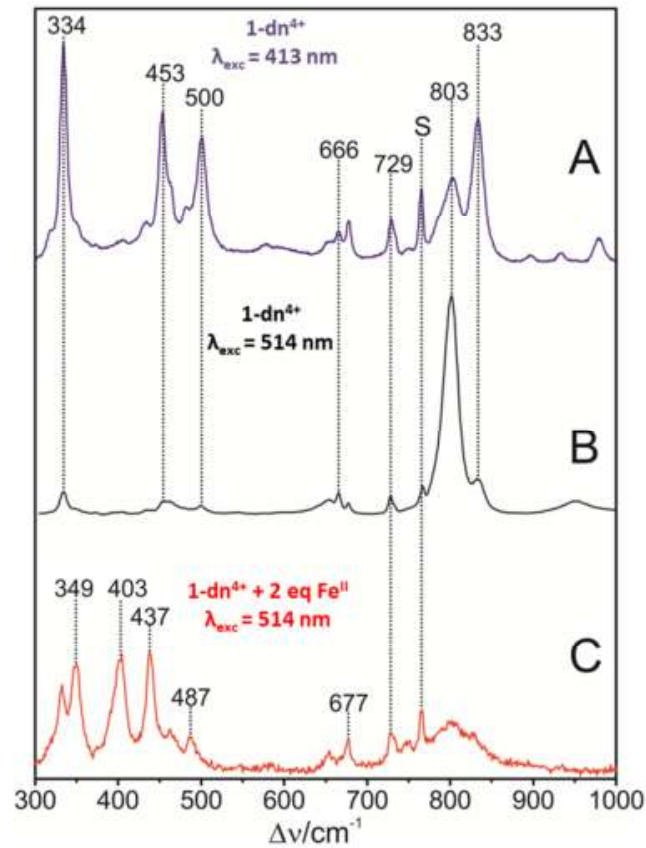

Figure 5. RR spectra of 1-dn $\mathbf{n}^{4+}$ in the oxidation state IV,IV obtained with (A) $413 \mathrm{~nm}$ (blue) and (B) $514 \mathrm{~nm}$ excitation (black), compared with the RR spectrum of $(\mathbf{C})$ the III,III form of the complex, generated after the addition of 2 equivalents of $\left(\mathrm{NH}_{4}\right)_{2} \mathrm{Fe}\left(\mathrm{SO}_{4}\right)_{2}$ to the 1-dn ${ }^{4+}$ (red), $514 \mathrm{~nm}$ excitation. "S" refers to a Raman band of triflic acid. Details of the RR experiments are given in the text.

\section{The $R u^{\mathrm{IV}}=0$ reactive intermediate}

Critical species of single-site Ru-pyridyl type of catalysts are the corresponding high oxidation states derived from the initial Ru"-
$\mathrm{OH}_{2}$ state, namely $\mathrm{Ru}^{\mathrm{IV}}=\mathrm{O}$ and $\mathrm{Ru}^{\mathrm{V}}=\mathrm{O}$ (Figure 1). Here we succeeded to obtain single crystals suitable for X-Ray diffraction analysis of the $\mathrm{Ru}^{\mathrm{IV}}=\mathrm{O}$ intermediate $\left[\mathrm{Ru}^{\mathrm{IV}}(\mathrm{O})(\operatorname{trpy})\left(5,5^{\prime}-\mathrm{F}_{2}-\mathrm{Bpy}\right)\right]^{2+}$ that is obtained from the removal of two protons and two electrons from $2^{2+}$. The corresponding ORTEP plot is shown in Figure 6. The structure consists of a $\mathrm{Ru}^{\mathrm{IV}}$ with distorted octahedral geometry with coordinated trpy, bpy and terminal oxo ligands. The oxo ligand displays a Ru-O distance of $1.85 \AA$ that confirms its double bond character as it falls within the range of previously reported related complexes. ${ }^{[27,30-36]}$ The complex crystallizes with a solvent water molecule that is hydrogen bonded to the oxygen atom of the $\mathrm{Ru}=\mathrm{O}$ group $\left(\mathrm{O}_{\text {oxo }}-\mathrm{O}_{\text {water }}=\right.$ $2.674 \AA ; \mathrm{O}_{\text {oxo }}-\mathrm{H}=1.982 \AA ; \mathrm{O}_{\text {water }}-\mathrm{H}=0.859 \AA ; \mathrm{O}_{\text {oxo }}-\mathrm{H}-\mathrm{O}_{\text {water }}=$ $\left.136.59^{\circ}\right)$. A particularly interesting feature of the structure is the remarkable elongation of the Ru-N bpy bond of $2.14 \AA$ located trans to the $\mathrm{Ru}=\mathrm{O}$ group. The same bond for the reduced complex $\left[R u^{\prime \prime}(\operatorname{trpy})\left(5,5^{\prime}-\mathrm{F}_{2}-\mathrm{bpy}\right)\left(\mathrm{H}_{2} \mathrm{O}\right)\right]^{2+}\left(2^{2+}\right)$ is only $2.02 \AA^{6}{ }^{6}$ These striking differences reflect the weakness of this Ru-N bond, favoring bpy decoordination and water substitution as we and others have suggested earlier. ${ }^{[14,16]}$ An even larger effect would be expected for the one electron oxidized species $\mathrm{Ru}^{\mathrm{V}}=\mathrm{O}$, that is proposed to undergo this bpy loss to generate $3^{2+}$ as shown in Figure 1.

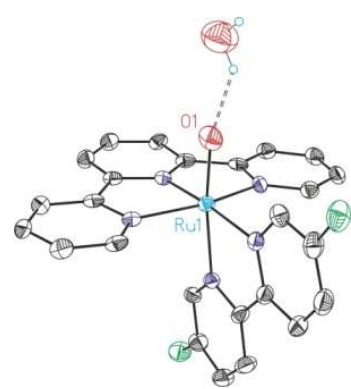

Figure 6. ORTEP plot (ellipsoid drawn at $50 \%$ probability) of the $\mathrm{X}$-ray diffraction structure of dication $\left\{\left[\mathrm{Ru}^{\mathrm{IV}}(\mathrm{O})(\text { trpy })\left(5,5^{\prime}-\mathrm{F}_{2}-\mathrm{bpy}\right)\right] \cdot \mathrm{H}_{2} \mathrm{O}\right\}^{2+}$ generally indicated as $\left[\mathrm{Ru}^{\mathrm{IV}}=\mathrm{O}^{2+}\right.$ in Figure 1. Color codes: Ru, cyan; O, Red; N, Blue; C, black; $F$, green. $\mathrm{H}$ atoms are not shown except for a crystallized water molecule forming a $\mathrm{H}$-bond with the oxo group.

\section{3-Time-dependent resonance Raman (RR) experiments}

RR spectra of the mononuclear complexes $\mathbf{1}^{2+}$ and $\mathbf{2}^{2+}$ were measured with $413 \mathrm{~nm}$ laser excitation which is in resonance with a metal-ligand charge transfer transition ${ }^{[5]}$ presumably involving the bidentate ligand (Figure 7A). As a consequence, the vibrational band patterns differ quite substantially for $\mathbf{1}^{2+}$ and $2^{2+}$ in the entire spectral range. Here we focused on the region below $1000 \mathrm{~cm}^{-1}$ to monitor the modes containing coordinates of 
"This is the peer reviewed version of the following article:

Electrochemical and Resonance Raman Spectroscopic Studies of Water-Oxidizing Ruthenium-

Terpyridyl-Bipyridyl Complexes, which has been published in final form at http://onlinelibrary.wiley.com/doi/10.1002/cssc.201601221/abstract

This article may be used for non-commercial purposes in accordance with Wiley Terms and Conditions for SelfArchiving."

the oxygen ligands. For the reduced parental species, these modes are not detectable as verified by the lack of any ${ }^{18} \mathrm{O} /{ }^{16} \mathrm{O}$ and ${ }^{2} \mathrm{H} /{ }^{1} \mathrm{H}$-sensitive bands.

\subsection{Stoichiometric oxidation of Ru" complexes}

We first studied the stoichiometric oxidation of $\mathbf{1}^{2+}$, using two equivalents of $\mathrm{Ce}^{\mathrm{IV}}$ (Figure 7 , left). Immediately after addition of the oxidant, the band intensities of the Rull complex (i.e., at 667, 676 , and $729 \mathrm{~cm}^{-1}$ ) strongly decreased with respect to the solvent band whereas new bands at 719,798 , and $919 \mathrm{~cm}^{-1}$ appeared (Figure 7B). The stoichiometric oxidation of $\mathbf{2}^{2+}$ (Figure 7 , right) offers a similar picture as far as the intensity loss of the $\mathrm{Ru}^{\prime \prime}$ bands and the concomitant increase of the product bands at $657,719,800,879$, and $919 \mathrm{~cm}^{-1}$ are concerned (Figure 7B). Like the $798 \mathrm{~cm}^{-1}$ band of the oxidation product of $1^{2+}$, the band at $800 \mathrm{~cm}^{-1}$ of $2^{2+}$ has decayed after $24 \mathrm{~h}$ (Figure $7 \mathrm{C}$ ). The temporal evolution of these bands after addition of $\mathrm{Ce}^{\mathrm{IV}}$ indicates that the stoichiometric oxidation of the mononuclear complexes involves two spectroscopically detectable states, characterized by the bands with red and green colored labels in Figure 7 B,C. Essentially the same results were obtained upon addition of three instead of two oxidation equivalents, except for a faster decay of the $800(798) \mathrm{cm}^{-1}$ bands (red label) and a somewhat larger contribution of the "green" species compared to the parent states.

This band at $800 \mathrm{~cm}^{-1}$ is of particular interest since it can be assigned to the mononuclear $\mathrm{Ru}^{\mathrm{IV}}=\mathrm{O}$ or $\mathrm{Ru}^{\mathrm{V}}=\mathrm{O}$ species (see scheme in Figure 7, red labels), in line with the assignment for related dinuclear complexes $\mathbf{1 - d \mathbf { n } ^ { 4 + }}$ and $\mathbf{2 - \mathbf { d n } ^ { 4 + }}$ also containing a $\mathrm{Ru}=\mathrm{O}$ group (see Figure 5, vide supra).$^{[16]}$ Indeed, isotopic labeling experiments using $\mathrm{H}_{2}{ }^{18} \mathrm{O}$ show the expected $40 \mathrm{~cm}^{-1}$ shift of the Ru=O resonance from $800 \mathrm{~cm}^{-1}$ to $760 \mathrm{~cm}^{-1}$ (Figure S4).

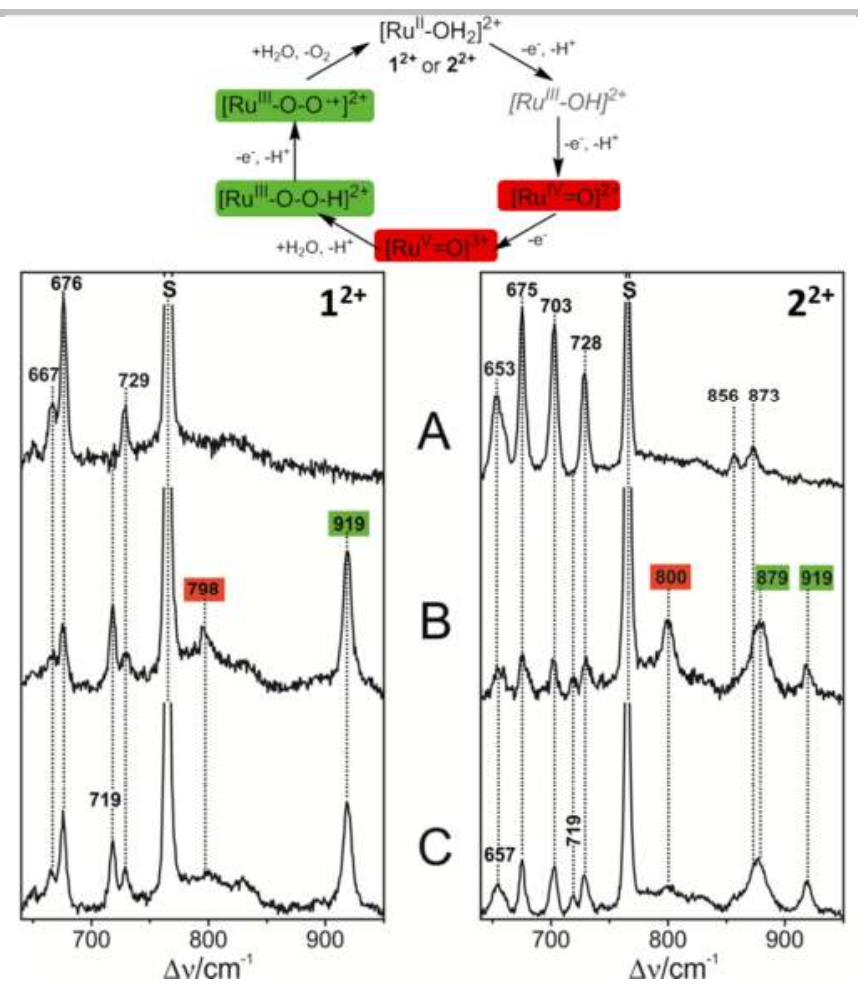

Figure 7. RR spectra of $\mathbf{1}^{2+}$ and $\mathbf{2}^{2+}$ measured upon stoichiometric oxidation with 2 equivalents of $\mathrm{Ce}^{\mathrm{IV}}$. (A) parental reduced $\mathrm{Ru}^{\mathrm{II}}$ state; (B) 30 seconds after addition of $\mathrm{Ce}^{\mathrm{IV}} ;$ (C) $24 \mathrm{~h}$ after addition of $\mathrm{Ce}^{\mathrm{IV}}$. The spectra were obtained with $413 \mathrm{~nm}$ excitation at room temperature. "S" refers to a Raman band of triflic acid. The color code of the RR band labels is related to the reaction scheme indicated at the top of the figure.

The nature of the oxidized species with resonances at $879 \mathrm{~cm}^{-1}$ (only for $\mathbf{2}^{2+}$ ) and $919 \mathrm{~cm}^{-1}$ (for both $\mathbf{1}^{2+}$ and $\mathbf{2}^{2+}$ ) was assessed through the stoichiometric oxidation of $2^{2+}$ in pure $\mathrm{H}_{2}{ }^{16} \mathrm{O}$ or $\mathrm{H}_{2}{ }^{18} \mathrm{O}$, and a $1: 1$ mixture of $\mathrm{H}_{2}{ }^{16} \mathrm{O}$ and $\mathrm{H}_{2}{ }^{18} \mathrm{O}$ (Figure 8). In this case, the ${ }^{18} \mathrm{O} /{ }^{16} \mathrm{O}$ shift was only $6 \mathrm{~cm}^{-1}$ and thus much smaller than that expected for a $\mathrm{Ru}=\mathrm{O}$ containing modes (ca. $40 \mathrm{~cm}^{-1}$ band). ${ }^{[16]}$ For the $1: 1$ mixture of $\mathrm{H}_{2}{ }^{16} \mathrm{O}$ and $\mathrm{H}_{2}{ }^{18} \mathrm{O}$, a broad peak is observed that evidently involves more than one band. The 919 $\mathrm{cm}^{-1}$ band lies within the range of the O-O fragment stretching modes for which quite different values of $\Delta u$ have been observed in the past. ${ }^{[11,28]}$ Although typical isotopic shift values of ca. 50 $\mathrm{cm}^{-1}$ are expected for $\mathrm{a}^{18} \mathrm{O} /{ }^{16} \mathrm{O}$ substitution in the O-O fragment, distinctly smaller shifts below $20 \mathrm{~cm}^{-1}$ have been reported for Ru compounds that were assigned to peroxo or superoxo derivatives. ${ }^{[11]}$ Such small shifts suggest a distribution of the O-O stretching coordinate and thus of the isotopic shift among several modes. Accordingly, this $919 \mathrm{~cm}^{-1}$ band can be ascribed to the O-O stretching of either the $\mathrm{Ru}^{\mathrm{III}}$ hydroperoxo [Ru'II-O-O- 
"This is the peer reviewed version of the following article: Electrochemical and Resonance Raman Spectroscopic Studies of Water-Oxidizing Ruthenium-
Terpyridyl-Bipyridyl Complexes, which has been published in final form at
http://onlinelibrary.wiley.com/doi/10.1002/cssc.201601221/abstract

This article may be used for non-commercial purposes in accordance with Wiley Terms and Conditions for SelfArchiving."

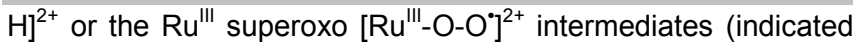
as green labels in the catalytic cycle depicted in Figure 7), ${ }^{[16]}$ which is in line with a previous suggestions. ${ }^{[3,15 a]}$ Moreover, the $\mathrm{H} / \mathrm{D}$ sensitivity of this band favors the assignment to the hydroperoxo complex although the $H / D$ shift cannot be determined precisely (Fig. S5). All other bands originating from the same peroxido complex, are attributed to modes of the polypyridyl ligands since they did not display any ${ }^{18} \mathrm{O} /{ }^{16} \mathrm{O}$ shift and are found at similar position as their counterparts in the parent (reduced) complexes.

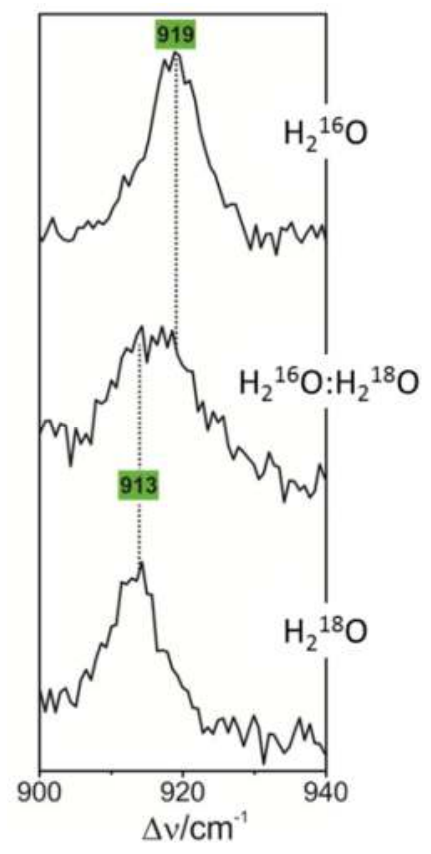

Figure 8. Section of the RR spectrum associated with the "O-O" fragment. The spectra were obtained from solutions of $2^{2+}$ and measured 24 hours after the addition of 2 equivalents of $\mathrm{Ce}^{\mathrm{IV}}$ in $\mathrm{H}_{2}{ }^{16} \mathrm{O}$ (top), in a $1: 1$ mixture of $\mathrm{H}_{2}{ }^{18} \mathrm{O} / \mathrm{H}_{2}{ }^{16} \mathrm{O}$ (middle) and in $\mathrm{H}_{2}{ }^{18} \mathrm{O}$ (bottom). The green color of the band labels is related to the reaction scheme in Figure 7.

\subsection{Oxidation of $\mathrm{Ru}^{\prime \prime}$ complexes under turnover conditions}

We studied the oxidation of the mononuclear complexes $1^{2+}$ and $2^{2+}$ under turnover conditions, i.e. at a large $(100$-fold $)$ excess of $\mathrm{Ce}^{\mathrm{IV}}$. This process is accompanied by the clearly visible evolution of $\mathrm{O}_{2}$. Spectra were measured consecutively each 30 minutes after addition of the oxidant. Both complexes display the same time-dependent behavior as illustratively shown for the oxidation of $1^{2+}$ (Figure 9). Thirty minutes after $\mathrm{Ce}^{\mathrm{IV}}$ addition, the characteristic bands of $1^{2+}$, such as that at $676 \mathrm{~cm}^{-1}$, have disappeared and new bands at 835 and $717 \mathrm{~cm}^{-1}$ have grown in. After one hour, an additional band emerges at $799 \mathrm{~cm}^{-1}$ and after ca. two hours the process has evidently reached equilibrium concentrations. Thus, under turnover conditions, two different Ru species are detectable in the RR spectra, an "early" intermediate and a final product with the color labels yellow and blue, respectively (Figure 9). No signal at $919 \mathrm{~cm}^{-1}$ attributed to the $\mathrm{O}-\mathrm{O}$ vibration was observed in any of the spectra.

To identify these two species, the RR spectra of the reaction mixture at early (30 $\mathrm{min})$ and late times (120 min) were compared with those of separately synthesized and purified Ru reference complexes (Figure 10). Complex $3^{2+}$, that is suggested to be the intermediate connecting the monomeric and the dimeric water oxidation reaction cycles, shows a simple RR spectrum with only five bands in the range between 300 and 900 $\mathrm{cm}^{-1}$ (Figure 10B, yellow label). Four rather weak bands that are at positions very similar to those of $\mathbf{1}^{2+}$, i.e. at ca. 685 , and 734 $\mathrm{cm}^{-1}$, most likely originate from vibrational modes of the trpy ligand (compare Figure $10 \mathrm{~A}$ and $10 \mathrm{~B}$ ). The most intense band is observed at $835 \mathrm{~cm}^{-1}$ and is readily attributed to a mode including the $\mathrm{O}=\mathrm{Ru}=\mathrm{O}$ stretching coordinate. ${ }^{[21]}$ Only this mode can be identified in the "early" RR spectrum of the catalytic process, implying that soon after the addition of excess $\mathrm{Ce}^{\mathrm{IV}}$ the $\mathrm{Ru}^{\mathrm{VI}}$-dioxo complex $3^{2+}$ is formed. With increasing time, the 835 $\mathrm{cm}^{-1}$ band broadens concomitant to the growing-in of the 799 $\mathrm{cm}^{-1}$ band. The unusually broad shape of the $835 \mathrm{~cm}^{-1}$ band indicates the involvement of several components with similar frequencies. The comparison with the RR spectrum of isolated 1-dn ${ }^{4+}$ suggests that it is this dimer and closely related species (compare Figure $10 \mathrm{D}$ and $10 \mathrm{E}$, blue labels) that dominate the RR spectrum at "late" times. Note that the $833 \mathrm{~cm}^{-1}$ band of the

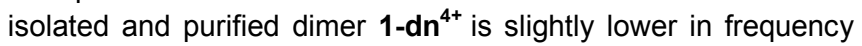
than the $\mathrm{O}=\mathrm{Ru}=\mathrm{O}$ stretching mode of $3^{2+}\left(835 \mathrm{~cm}^{-1}\right)$. Thus, it may well be that residual contributions of $3^{2+}$ species also contribute to the broadening of $835 \mathrm{~cm}^{-1}$ band.

\subsection{Implications for the reaction mechanism}

Time-resolved RR spectroscopy of a chemical reaction probes the actual composition of the sample solution at given delay times with respect to the addition of the oxidant. However, the $\mathrm{RR}$ spectra do not reflect the true relative concentrations of the reaction mixture, since at a given excitation line the relative and absolute Raman cross sections of the individual species may be quite different. For this reason and due to unfavorable kinetics not all intermediate states that are involved can be detected in the time-dependent $\mathrm{RR}$ experiments. For instance, the primary oxidation product of $\mathrm{Ru}^{\text {II }}-\mathrm{OH}_{2}$, i.e. $\mathrm{Ru}$ 'III-OH (or $\mathrm{Ru}^{\text {II }}-\mathrm{OH}_{2}$ at $\mathrm{pH}$ 1), is not detected at any time, although it has to be transiently formed as proven by EPR spectroscopy. ${ }^{[11 b]}$ 
"This is the peer reviewed version of the following article:

Electrochemical and Resonance Raman Spectroscopic Studies of Water-Oxidizing Ruthenium-

Terpyridyl-Bipyridyl Complexes, which has been published in final form at http://onlinelibrary.wiley.com/doi/10.1002/cssc.201601221/abstract

This article may be used for non-commercial purposes in accordance with Wiley Terms and Conditions for SelfArchiving."

We first consider the stoichiometric oxidation of $\mathrm{Ru}^{\prime \prime}$ which requires hours to reach the chemical equilibrium. In the presence of 2 and 3 equivalents of $\mathrm{Ce}^{\mathrm{IV}}$ the originally proposed reaction scheme (Figure 1 ) implies that the reaction can only run up to the $\mathrm{Ru}^{\mathrm{IV}}=\mathrm{O}$ and $\mathrm{Ru}^{\mathrm{V}}=\mathrm{O}$ complexes. While the latter is $\mathrm{EPR}$ active, the first is EPR silent so the best way to detect it is by using $\mathrm{rR}$ spectroscopy due to strong signature of the $\mathrm{Ru}=\mathrm{O}$ vibrations. In fact, in both cases ( 2 and 3 equivalents of $\mathrm{Ce}^{\mathrm{IV}}$ ) we note the formation of a $\mathrm{Ru}=\mathrm{O}$ species from $\mathbf{1}^{2+}$ and $\mathbf{2}^{2+}$ in the first spectra measured immediately after addition of the oxidant (Figure 7B). These reactions may be rather fast (minute time scale). However, under these conditions the $\mathrm{Ru}=\mathrm{O}$ species can slowly decay to the $\left[\mathrm{Ru}^{\mathrm{III}}-\mathrm{O}-\mathrm{O}^{+}\right]^{2+}$ or, more likely, $\left[\mathrm{Ru} \mathrm{u}^{\mathrm{III}}-\mathrm{O}-\mathrm{O}-\mathrm{H}\right]^{2+}$ complex (Figure 7C), via the proposed disproportionation reaction indicated in Eq. 4-5.

$$
\begin{aligned}
& 2\left[\mathrm{Ru}^{\mathrm{IV}}=\mathrm{O}\right]^{2+}+\mathrm{H}^{+} \longrightarrow\left[\mathrm{Ru}^{\mathrm{V}}=\mathrm{O}\right]^{3+}+\left[\mathrm{Ru} \mathrm{u}^{\mathrm{III}}-\mathrm{OH}\right]^{2+} \\
& {\left[\mathrm{Ru}^{\mathrm{V}}=\mathrm{O}\right]^{3+}+\mathrm{H}_{2} \mathrm{O} \longrightarrow\left[\mathrm{Ru}^{\mathrm{III}}-\mathrm{OOH}\right]^{2+}+\mathrm{H}^{+}} \\
& 2\left[\mathrm{Ru}^{\mathrm{IV}}=\mathrm{O}\right]^{2+}+\mathrm{H}_{2} \mathrm{O} \longrightarrow\left[\mathrm{Ru}^{\mathrm{III}}-\mathrm{OOH}\right]^{2+}+\left[\mathrm{Ru} \mathrm{u}^{\mathrm{III}}-\mathrm{OH}\right]^{2+}
\end{aligned}
$$

A pathway that we have previously found and discussed for related complexes. ${ }^{[37]}$ However other potential pathways for the generation of $\left[\mathrm{Ru}^{\mathrm{III}}-\mathrm{O}-\mathrm{O}-\mathrm{H}\right]^{2+}$ involving $\mathrm{Ce}^{\mathrm{IV}}$ may exist as proposed by Sakai et al. ${ }^{[15]}$

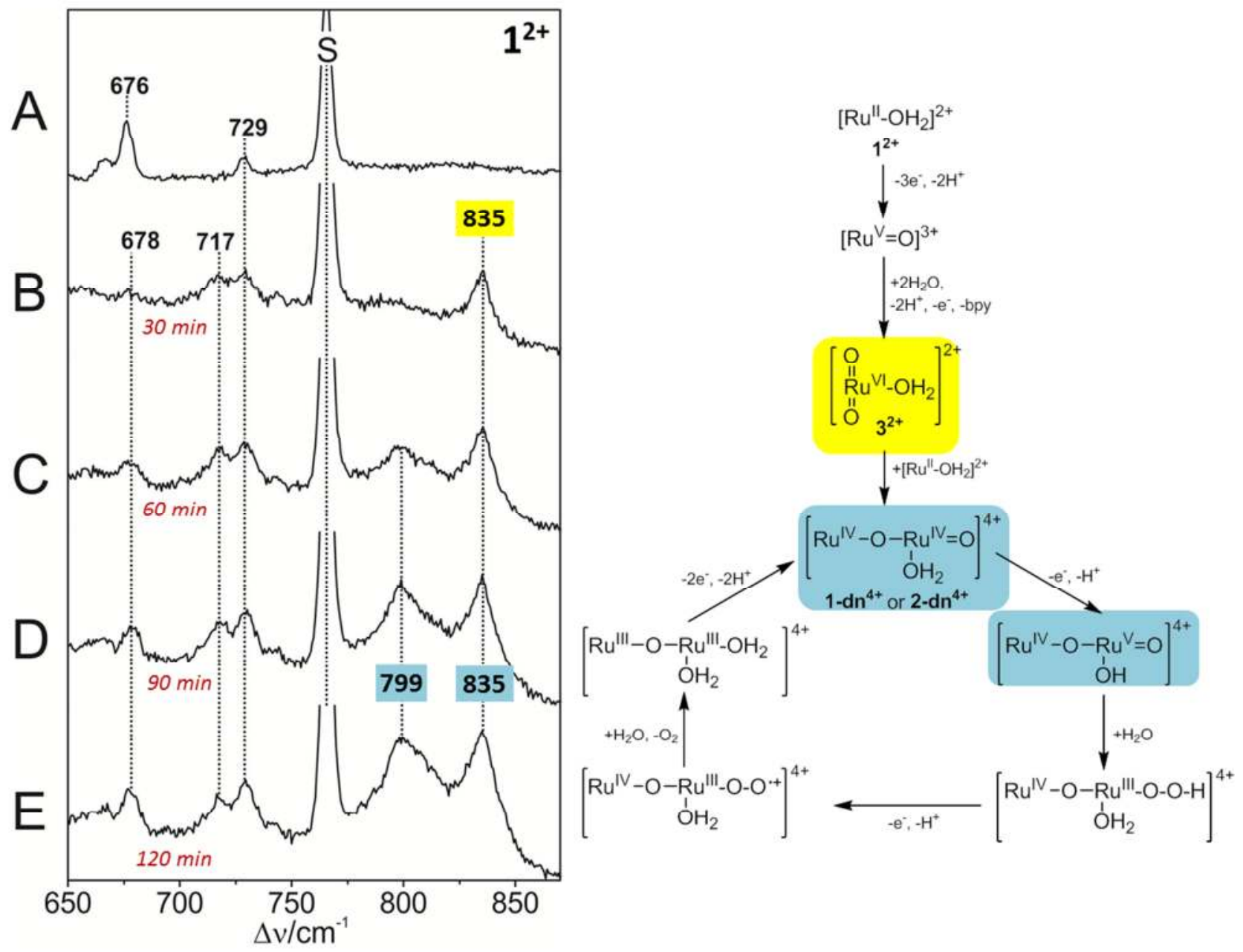


"This is the peer reviewed version of the following article:

Electrochemical and Resonance Raman Spectroscopic Studies of Water-Oxidizing Ruthenium-

Terpyridyl-Bipyridyl Complexes, which has been published in final form at http://onlinelibrary.wiley.com/doi/10.1002/cssc.201601221/abstract

This article may be used for non-commercial purposes in accordance with Wiley Terms and Conditions for SelfArchiving."

Figure 9. RR spectra of $\mathbf{1}^{2+}$ measured upon oxidation with excess (100 equivalents) of Ce ${ }^{\mathrm{IV}}$. (A) parental reduced Ru" state; (B) 30 min after addition; (C) 60 min after addition; (D) 90 min addition; (E) 120 min after addition. The spectra were obtained with 413 nm excitation at room temperature. "S" refers to a Raman band of triflic acid. The color code of the band labels is related to the reaction scheme depicted in the right of the figure.

This finding also implies that the monomeric $\mathbf{1}^{2+}$ and $\mathbf{2}^{2+}$ complexes are catalytically competent insofar as they catalyse $\mathrm{O}-\mathrm{O}$ bond formation from water. The identification of the $\mathrm{O}_{2-}$ releasing state to a $\mathrm{Ru}^{\mathrm{III}}$ (superoxo) hydroperoxo complex confirms previous suggestions in the literature. ${ }^{[3,15 a]}$

This disproportionation reaction seems to play only a minor role upon oxidation of $\mathrm{Ru}^{\mathrm{II}}$ with large excess of $\mathrm{Ce}^{\mathrm{IV}}$ as the signal attributed to [Ru-O-O] ${ }^{\mathrm{n}+}$ type of complexes is very weak under these conditions (Fig. S6). The spectrally prevalent species at early times is instead the trans-dioxo $\mathrm{Ru}^{\mathrm{Vl}}$ complex $3^{2+}$ that according to the proposed scheme links the monomeric and dimeric reaction cycle (Figure 1 and 9). Using a 100-fold excess of $\mathrm{Ce}^{\mathrm{IV}}$, the reaction runs repetitively through the dinuclear cycle under evolution of $\mathrm{O}_{2}$. Here the RR spectra only reveal contributions from $\mathbf{1 - d n ^ { 4 + }}$ and $\mathbf{3}^{2+}$ (Figure 9 and 10). The failure to detect other intermediates of the reaction scheme may either be due to their low resonance enhancement or their short lifetime due to fast decay kinetics. Consequently, the species contributing to the RR spectra measured during turnover and after consumption of all oxidizing equivalents are nearly the same. It is important to keep in mind that the RR analysis does not provide a quantitate analysis related to the relative amount of the species in the reaction sequence and thus only give a qualitative picture.

Altogether, the results of the present study are fully consistent with the previously proposed reaction scheme (Figure 1), demonstrating that formation of dinuclear complex $1-\mathbf{d n}^{4+}$ is essential for an efficient catalytic process, especially if long lasting performance is needed for potential technological applications.

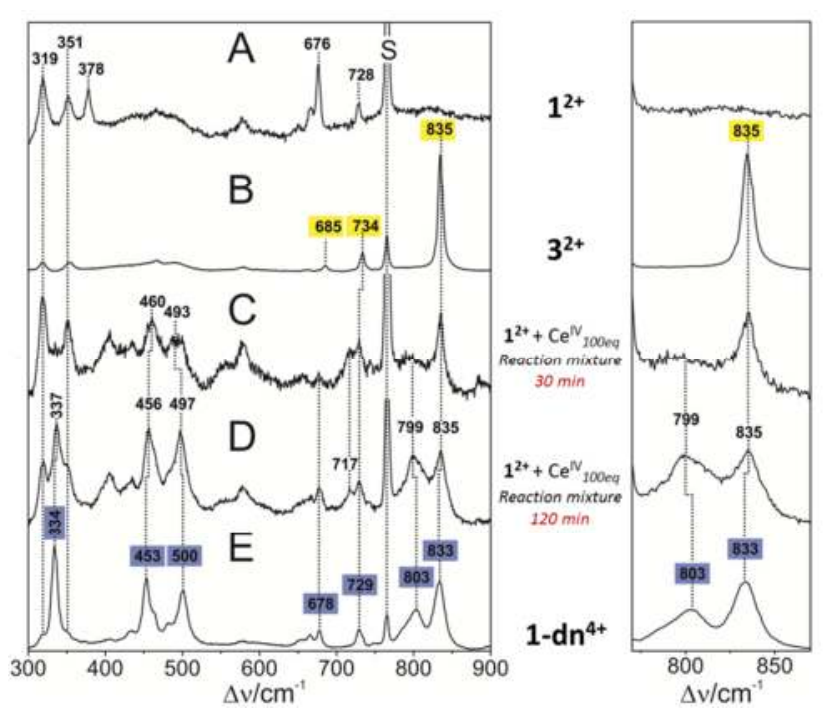

Figure 10. RR spectra of $1^{2+}$ measured upon oxidation with excess (100 equivalents) of $\mathrm{Ce}^{\mathrm{IV}}$, compared with the RR spectra of reference complexes. (A) pure $1^{2+} ;$ (B) pure $3^{2+} ;$ (C) $1^{2+}, 30$ min after Ce $\mathrm{IV}^{\mathrm{IV}}$ addition; (D) $\mathbf{1}^{2+}, 120 \mathrm{~min}$

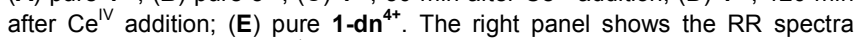
between 770 and $870 \mathrm{~cm}^{-1}$ on an expanded view. The spectra were obtained with $413 \mathrm{~nm}$ excitation at ambient temperature. "S" refers to a Raman band of triflic acid. The color code of the band labels is related to the reaction scheme in Figure 9.

\section{Conclusions}

In a previous study we demonstrated that single-site WOCs structurally related to $\mathbf{1}^{2+}$ evolved to oxo-bridge dinuclear complexes which are rugged catalysts. The presented work constitutes a mandatory continuation where the electrochemical and acid-base properties of the dinuclear compounds $1-\mathrm{dn}^{4+}$ and 2-dn ${ }^{4+}$ have been thoroughly examined. $1-\mathbf{d n}^{4+}$ shows two $\mathrm{pH}-$ dependent 2 electron waves in cyclic voltammetry. The wave attributed to the IV,IV/III,III couple is associated with the double protonation of the terminal oxo ligand of IV,IV according to the Pourbaix diagram. The second wave proceeds from the III,III/II,II couple and is associated with protonation of the oxo bridge ligand according to its $\mathrm{pH}$-dependency. The $\mathrm{pK}_{\mathrm{a}}$ values of the aquo ligands in IV,IV and III,III were determined spectrophotometrically. Both values are quite similar $\left(\mathrm{pK}_{\mathrm{a}}(\mathrm{IV}, \mathrm{IV})\right.$ $=4.4$ and $\left.\mathrm{pK}_{\mathrm{a}}(\mathrm{III}, \mathrm{III})=4.3\right)$, accounting for the constant slope for 


\title{
"This is the peer reviewed version of the following article: \\ Electrochemical and Resonance Raman Spectroscopic Studies of Water-Oxidizing Ruthenium- Terpyridyl-Bipyridyl Complexes, which has been published in final form at http://onlinelibrary.wiley.com/doi/10.1002/cssc.201601221/abstract
}

\author{
This article may be used for non-commercial purposes in accordance with Wiley Terms and Conditions for Self- \\ Archiving."
}

the two couples in the Pourbaix diagram. Additionally, the $\mathrm{pK}_{\mathrm{a}}$ for the IV,IV oxidation state of $\mathbf{2 - \mathbf { d n } ^ { 4 + }}$ was found to be slightly lower than that for $1-\mathbf{d n}^{4+}(4.0$ vs. 4.4$)$, which is consistent with the electron-withdrawing effect exerted by the fluorine atoms of the bpy ligand.

The conversion of $\mathbf{1}^{2+}$ to $1-\mathbf{d n}^{4+}$ was studied thoroughly by in situ RR spectroscopy after the addition of stoichiometric amounts or an excess, that is under catalytic conditions, of $\mathrm{Ce}^{\mathrm{IV}}$. In the first case we have observed two different species which can be assigned to $[\mathrm{Ru}=\mathrm{O}]^{\mathrm{n}+}$ and $[\mathrm{Ru}-\mathrm{O}-\mathrm{O}]^{\mathrm{n+}}$ type of complexes. Under turnover conditions, the intermediate appearing immediately after the addition of the oxidant was unambiguously identified as the trans-dioxo complex $3^{2+}$. The second species that accumulated later during catalytic turnover is the crucial dinuclear complex $1-\mathbf{d n}^{\mathbf{4}^{+}}$. These findings support our previously proposed mechanism and complete the characterization of most of the envisaged intermediates.

Finally, the X-Ray structure of the oxidation state IV from $2^{2+}$ evidences the proposed trans effect exerted by the oxo group and that eventually leads to the release of the bpy ligand and the consecutive formation of $3^{2+}$. This critical process constitutes the origin of the formation of the highly rugged dinuclear WOCs 1 $\mathrm{dn}^{4+}$ and 2-dn ${ }^{4+}$.

\section{Experimental Section}

Materials. $\mathrm{RuCl}_{3} \cdot 3 \mathrm{H}_{2} \mathrm{O}$ was supplied by Alfa Aesar and was used as received. Trifluoromethanesulfonic acid (HOTf) was purchased from CYMIT. All other reagents used in the present work were obtained from Aldrich Chemical Co. and were used without further purification. Reagent-grade organic solvents were obtained from SDS and high-purity deionized water was obtained by passing distilled water through a nanopure Milli- $Q$ water purification system.

Preparations. [Ru'(trpy)(bpy) $\left.\left(\mathrm{H}_{2} \mathrm{O}\right)\right]\left(\mathrm{PF}_{6}\right)_{2} \quad\left(1^{2+}\right),{ }^{[23]} \quad\left[\mathrm{Ru}^{\prime \prime}(\operatorname{trpy})\left(5,5^{\prime}-\mathrm{F}_{2^{-}}\right.\right.$

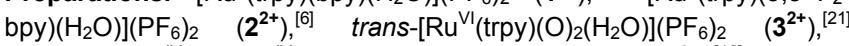
$\left[(\operatorname{trpy})(\mathrm{bpy}) \mathrm{Ru}^{\mathrm{IV}}(\mu-\mathrm{O}) \mathrm{Ru}^{\mathrm{IV}}(\operatorname{trpy})(\mathrm{O})\left(\mathrm{H}_{2} \mathrm{O}\right)\right]\left(\mathrm{ClO}_{4}\right)_{4} \quad\left(\mathbf{1 - \mathbf { d n } ^ { 4 + }}\right),{ }^{[16]}$ and $\left[(\right.$ trpy $)\left(5,5^{\prime}-\mathrm{F}_{2}\right.$-bpy $\left.) \mathrm{Ru}^{\mathrm{IV}}(\mu-\mathrm{O}) \mathrm{Ru}^{\mathrm{IV}}(\operatorname{trpy})(\mathrm{O})\left(\mathrm{H}_{2} \mathrm{O}\right)\right]\left(\mathrm{ClO}_{4}\right)_{4} \quad\left(\mathbf{2}-\mathbf{d n}^{4+}\right)^{[16]}$ were prepared as described in the literature. Warning. Perchlorate salts are hazardous because of the possibility of explosion. They should be prepared in small amounts, stored appropriately and not warmed above $40^{\circ} \mathrm{C}$.

Samples for RR spectroscopy using $514 \mathrm{~nm}$ excitation were prepared by mixing a $1 \mathrm{mM}$ solution of $1-\mathbf{d n}^{4+}$ in $0.1 \mathrm{M}$ triflic acid $(\mathrm{pH} \mathrm{1.0)}$ with two equivalents of $\left(\mathrm{NH}_{4}\right)_{2} \mathrm{Fe}\left(\mathrm{SO}_{4}\right)_{2}$ ( $\mathrm{Fe}$ "I in text). $100 \mu \mathrm{L}$ of the reaction solution were transferred to an aluminium crucible and subsequently frozen in liquid $\mathrm{N}_{2}$. Then, the crucible was placed into a Linkam THMS 600 temperature-controlled cryostage to keep the temperature at $-12{ }^{\circ} \mathrm{C}$. For RR measurements using $413 \mathrm{~nm}$ excitation, the complexes were dissolved in triflic acid at $\mathrm{pH} 1.0$ with a concentration of $1 \mathrm{mM}$. Spectra were measured at ambient temperature. For determining ${ }^{18} \mathrm{O} /{ }^{16} \mathrm{O}$ isotopic shifts, the experiments were carried out in $\mathrm{H}_{2}{ }^{16} \mathrm{O}, \mathrm{H}_{2}{ }^{18} \mathrm{O}$, and $1: 1$ mixtures of $\mathrm{H}_{2}{ }^{16} \mathrm{O}$ and $\mathrm{H}_{2}{ }^{18} \mathrm{O}$. Oxidation of the $\mathrm{Ru}(\mathrm{II})$ complexes was achieved by addition of $\left[\left(\mathrm{NH}_{4}\right)_{2} \mathrm{Ce}\left(\mathrm{NO}_{3}\right)_{6}\right]\left(\mathrm{Ce}^{\mathrm{IV}}\right.$ in text).

Methods. UV/Vis spectroscopy was carried out with a Cary 50 (Varian) UV/Vis spectrophotometer. Cyclic voltammetry $(\mathrm{CV})$ and differential pulse voltammetry (DPV) experiments were performed using a IJ-Cambria $\mathrm{CHI}-$ 660 or a Bio-Logic SP-150 potentiostat controlling a three-electrode cell. Typical CV experiments were carried out at a scan rate of $100 \mathrm{mV} \mathrm{s}^{-1}$. For DPV experiments, we used a pulse height and width of $50 \mathrm{mV}$ and $50 \mathrm{~ms}$, respectively. The step height and step time was set to $4 \mathrm{mV}$ and $200 \mathrm{~ms}$, respectively. A glassy carbon electrode (3 mm diameter) was used as working electrode, platinum wire as auxiliary electrode, and a SSCE or $\mathrm{Hg} / \mathrm{Hg}_{2} \mathrm{SO}_{4}$ (sat. $\mathrm{K}_{2} \mathrm{SO}_{4}$ ) as reference electrode. Working electrodes were polished with 0.05 micron alumina paste and rinsed with distilled water and acetone followed by blow-drying before each measurement. For activation of glassy carbon electrodes, a procedure described by Meyer et al. was used. ${ }^{\left[{ }^{38]}\right.}$ All CVs presented in this work were recorded in the absence of light and inside a Faraday cage. The electrochemical experiments were carried out in $1 \mathrm{M} \mathrm{HOTf}(\mathrm{pH} 0.0)$ or $0.1 \mathrm{M} \mathrm{HOTf}(\mathrm{pH} \mathrm{1.0)}$. For higher $\mathrm{pH}$ values, different buffers were used, $\mathrm{NaH}_{2} \mathrm{PO}_{4} / \mathrm{H}_{3} \mathrm{PO}_{4}(\mathrm{pH}$ range $2.0-4.0), \mathrm{Na}_{2} \mathrm{HPO}_{4} / \mathrm{NaH}_{2} \mathrm{PO}_{4}(\mathrm{pH}$ range $=$ $4.0-8.0$ ), sodium tetraborate $(\mathrm{pH}$ range $8.0-9.5)$. In each case, the ionic strength was set to $0.1 \mathrm{M}$. $E_{1 / 2}$ values reported in this work were estimated from the oxidative and reductive peak potentials in $\mathrm{CV}$ experiments, i.e. $\left(E_{\mathrm{p}, \mathrm{a}}+E_{\mathrm{p}, \mathrm{c}}\right) / 2$, or as the potential at maximum current $E\left(I_{\max }\right)$ in DPV measurements.

RR spectra at $514 \mathrm{~nm}$ excitation were measured using a Renishaw inVia Reflex RAMAN confocal microscope (Gloucestershire, UK), equipped with an $\mathrm{Ar}$ ion laser. The spectrometer was equipped with a Peltiercooled CCD detector $\left(-70^{\circ} \mathrm{C}\right)$ coupled to a Leica DM-2500 microscope. Calibration was carried out with respect to the Raman spectrum of an $\mathrm{Si}$ standard. Spectra were recorded with an accumulation of $5 \times 20 \mathrm{~s}$. A 10x working distance microscope objective was used to focus the laser beam (25 $\mathrm{mW}$ ) onto the sample.

$\mathrm{RR}$ spectra with $413 \mathrm{~nm}$ excitation ( $\mathrm{Kr}$ ion laser) were measured using a confocal Raman spectrometer (LabRAM HR800, Horiba), equipped with a liquid-nitrogen cooled CCD detector. The laser beam $(10 \mathrm{~mW})$ was focused onto the sample contained in a rotating quartz cell. The total accumulation time of the spectra was ca. 10 minutes at room temperature. The spectral resolution was ca. $2 \mathrm{~cm}^{-1}$. Details of the experimental set-up were described elsewhere. ${ }^{[39]}$

Single-Crystal X-Ray Structure Determination. Single crystals of $\left[\operatorname{Ru}^{\mathrm{IV}}(\mathrm{O})(\right.$ trpy $)\left(5,5^{\prime}-\mathrm{F}_{2}\right.$-bpy) $]\left(\mathrm{PF}_{6}\right)_{2}$ were grown for 4 days after the dropwise addition of an aqueous saturated $\mathrm{NH}_{4} \mathrm{PF}_{6}$ solution to a reaction mixture of 3 equivalents of $\mathrm{Ce}^{\mathrm{IV}}$ and $2^{2+}$ in $0.1 \mathrm{M}$ HOTf that was previously left reacting for one day. All crystals were prepared under inert conditions immersed in perfluoropolyether as the protecting oil for manipulation.

Data collection. Crystal structure determination was carried out using a Apex DUO Kappa 4-axis goniometer equipped with an APPEX $24 \mathrm{~K} \mathrm{CCD}$ area detector, a Microfocus Source E025 luS using MoK $\mathrm{K}_{\alpha}$ radiation, Quazar MX multilayer Optics as monochromator, and an Oxford Cryosystems low temperature device Cryostream 700 plus $\left(T=-173^{\circ} \mathrm{C}\right)$. Full-sphere data collection was used with $\omega$ and $\varphi$ scans. Data collection and reduction were carried out with the programs APEX-2 and Bruker Saint19 V/.60A, respectively. ${ }^{[40,41]}$ 
"This is the peer reviewed version of the following article:

Electrochemical and Resonance Raman Spectroscopic Studies of Water-Oxidizing Ruthenium-

Terpyridyl-Bipyridyl Complexes, which has been published in final form at http://onlinelibrary.wiley.com/doi/10.1002/cssc.201601221/abstract

This article may be used for non-commercial purposes in accordance with Wiley Terms and Conditions for SelfArchiving."

Structure Solution and Refinement. Crystal structure solution was achieved using direct methods as implemented in SHELXTL ${ }^{[42]}$ and visualized using the program XP. Missing atoms were subsequently located from difference Fourier synthesis and added to the atom list. Least-square refinement on F2 using all measured intensities was carried out using the program SHELXTL. All non-hydrogen atoms were refined including anisotropic displacement parameters.

\section{Acknowledgements}

The work was supported by the Cluster of Excellence UniCat and the IRTG 1524, funded by the DFG. A.L. thanks MINECO (CTQ-2013-49075-R, SEV-2013-0319, CTQ2014-52974-REDC), Feder Funds and AGAUR (2014 SGR 915), for financial support. The Fotofuel Network of Excellence 2014 and the EU COST actions CM1202 and CM1205 are also gratefully acknowledged. IL thanks FPU for a PhD grant.

Keywords: peroxido • resonance Raman - ruthenium • superoxido $\cdot$ water oxidation

[1] R. Zong and R. P. Thummel, J. Am. Chem. Soc. 2005, 127 12802-12803

[2] J. J. Concepcion, J. W. Jurss, J. L. Templeton and T. J. Meyer, J. Am. Chem. Soc. 2008, 130, 16462-16463.

[3] J. J. Concepcion, M.-K. Tsai, J. T. Muckerman and T. J. Meyer, J. Am. Chem. Soc. 2010, 132, 1545-1557.

[4] J. J. Concepcion, J. W. Jurss, M. R. Norris, Z. Chen, J. L. Templeton and T. J. Meyer, Inorg. Chem. 2010, 49, 1277-1279.

[5] D. J. Wasylenko, C. Ganesamoorthy, M. A. Henderson, B. D. Koivisto, H. D. Osthoff and C. P. Berlinguette, J. Am. Chem. Soc. 2010, 132, 16094-16106.

[6] S. Maji, I. López, F. Bozoglian, J. Benet-Buchholz and A. Llobet, Inorg. Chem. 2013, 52, 3591-3593.

[7] M. Murakami, D. Hong, T. Suenobu, S. Yamaguchi, T. Ogura and S. Fukuzumi, J. Am. Chem. Soc. 2011, 133, 11605-11613.

[8] J. D. Blakemore, N. D. Schley, D. Balcells, J. F. Hull, G. W. Olack, C. D. Incarvito, O. Eisenstein, G. W. Brudvig and R. H. Crabtree, J. Am. Chem. Soc. 2010, 132, 16017-16029.

[9] D. J. Wasylenko, R. D. Palmer, E. Schott and C. P. Berlinguette, Chem. Commun. 2012, 48, 2107-2109.

[10] M.-T. Zhang, Z. Chen, P. Kang and T. J. Meyer, J. Am. Chem. Soc. 2013, 135, 2048-2051.

[11] (a) D. E. Polyansky, J. T. Muckerman, J. Rochford, R. Zong, R. P. Thummel and E. Fujita, J. Am. Chem. Soc. 2011, 133, 1464914665. (b) Y. Pushkar, D. Moonshiram, V. Purohit, L. Yan, I. Alperovich, J. Am. Chem. Soc. 2014, 136, 11938-11945. (c) J. Honta, S. Tajima, T. Sato, K. Saito, T. Yui, M. Yagi, J. Photochem. Photob. A: Chem. 2015, 313, 126-130.

[12] J. L. Boyer, D. E. Polyansky, D. J. Szalda, R. Zong, R. P. Thummel and E. Fujita, Angew. Chem. Int. Ed. 2011, 50, 12600-12604.

[13] H. Yamazaki, T. Hakamata, M. Komi and M. Yagi, J. Am. Chem. Soc. 2011, 133, 8846-8849.
[14] D. J. Wasylenko, C. Ganesamoorthy, B. D. Koivisto, M. A. Henderson and C. P. Berlinguette, Inorg. Chem. 2010, 49, 22022209.

[15] a) A. Kimoto, K. Yamauchi, M. Yoshida, S. Masaoka, K. Sakai, Chem. Commun. 2012, 48, 239-241; b) S. Masaoka, K. Sakai, Chem. Lett. 2009, 38, 182-183.

[16] I. López, M. Z. Ertem, S. Maji, J. Benet-Buchholz, A. Keidel, U Kuhlmann, P. Hildebrandt, C. J. Cramer, V. S. Batista and A. Llobet, Angew. Chem. Int. Ed. 2014, 53, 205-209.

[17] A. Llobet, P. Doppelt and T. J. Meyer, Inorg. Chem. 1988, 27, 514 520.

[18] A. Llobet, M. E. Curry, H. T. Evans and T. J. Meyer, Inorg. Chem 1989, 28, 3131-3137.

[19] J. A. Gilbert, D. S. Eggleston, W. R. Murphy, D. A. Geselowitz, S W. Gersten, D. J. Hodgson and T. J. Meyer, J. Am. Chem. Soc. 1985, 107, 3855-3864.

[20] R. Schneider, T. Weyhermueller, K. Wieghardt and B. Nuber, Inorg. Chem. 1993, 32, 4925-4934.

[21] J. W. Jurss, J. J. Concepcion, J. M. Butler, K. M. Omberg, L. M. Baraldo, D. G. Thompson, E. L. Lebeau, B. Hornstein, J. R. Schoonover, H. Jude, J. D. Thompson, D. M. Dattelbaum, R. C. Rocha, J. L. Templeton and T. J. Meyer, Inorg. Chem. 2012, 51, 1345-1358.

[22] S. A. Adeyemi, A. Dovletoglou, A. R. Guadalupe and T. J. Meyer, Inorg. Chem. 1992, 31, 1375-1383.

[23] J. M. Mayer, Comments Inorg. Chem. 1988, 8, 125-135.

[24] K. J. Takeuchi, M. S. Thompson, D. W. Pipes and T. J. Meyer, Inorg. Chem. 1984, 23, 1845-1851.

[25] F. Bozoglian, S. Romain, M. Z. Ertem, T. K. Todorova, C. Sens, J. Mola, M. Rodril guez, I. Romero, J. Benet-Buchholz, X Fontrodona, C. J. Cramer, L. Gagliardi and A. Llobet, J. Am. Chem. Soc. 2009, 131, 15176-15187.

[26] S. Roeser, PhD Thesis, Universitat Rovira i Virgili, 2011.

[27] I. López, S. Maji, J. Benet-Buchholz and A. Llobet, Inorg. Chem. 2015, 54, 658-666.

[28] D. Moonshiram, J. W. Jurss, J. J. Concepcion, T. Zakharova, I. Alperovich, T. J. Meyer and Y. Pushkar, J. Am. Chem. Soc. 2012, 134, 4625-4636.

[29] a) J. K. Hurst, J. Zhou, Y. Lei, Inorg. Chem. 1992, 31, 1010-1017; b) H. Yamada, J. K. Hurst, J. Am. Chem. Soc. 2000, 122, 53035311.

[30] T. W. Welch, S. A. Ciftan, P. S. White and H. H. Thorp, Inorg Chem. 1997, 36, 4812-4821.

[31] C. M. Che, T. F. Lai and K. Y. Wong, Inorg. Chem. 1987, 26, 22892299.

[32] W.-C. Cheng, W.-Y. Yu, K.-K. Cheung and C.-M. Che, J. Chem Soc., Dalton Trans. 1994, 57-62.

[33] C. M. Che, W. T. Tang, W. T. Wong and T. F. Lai, J. Am. Chem. Soc. 1989, 111, 9048-9056.

[34] T. Kojima, K. Nakayama, K. Ikemura, T. Ogura and S. Fukuzumi, J. Am. Chem. Soc. 2011, 133, 11692-11700.

[35] W.-C. Cheng, W.-Y. Yu, J. Zhu, K.-K. Cheung, S.-M. Peng, C.-K. Poon and C.-M. Che, Inorg. Chim. Acta 1996, 242, 105-113. E. L. Lebeau, S. A. Adeyemi and T. J. Meyer, Inorg. Chem. 1998 37, 6476-6484.

[37] R. Roeser, P. Farras, F. Bozoglian, M. Martínez-Belmonte, J. Benet-Buchholz, A. Llobet, ChemSusChem 2011, 4, 197-207. 
"This is the peer reviewed version of the following article:

Electrochemical and Resonance Raman Spectroscopic Studies of Water-Oxidizing Ruthenium-

Terpyridyl-Bipyridyl Complexes, which has been published in final form at http://onlinelibrary.wiley.com/doi/10.1002/cssc.201601221/abstract

This article may be used for non-commercial purposes in accordance with Wiley Terms and Conditions for SelfArchiving."

[38] G. E. Cabaniss, A. A. Diamantis, W. R. Murphy, R. W. Linton and T. J. Meyer, J. Am. Chem. Soc. 1985, 107, 1845-1853.

[39] H. K. Ly, T. Utesch, I. Díaz-Moreno, J. M. García-Heredia, M. Á. De La Rosa and P. Hildebrandt, J. Phys. Chem. B 2012, 116 5694-5702.
[40]
Data collection with APEX II, v2009.1-0.2, Bruker AXS Inc., Madison, Wisconsin, USA, 2009.

Data reduction with Buker SAINT V7.60A, Bruker AXS Inc., Madison, Wisconsin, USA, 2007

G. Sheldrick, Acta Crystallographica Section A 2008, 64, 112-122. 
"This is the peer reviewed version of the following article:

Electrochemical and Resonance Raman Spectroscopic Studies of Water-Oxidizing RutheniumTerpyridyl-Bipyridyl Complexes, which has been published in final form at http://onlinelibrary.wiley.com/doi/10.1002/cssc.201601221/abstract

This article may be used for non-commercial purposes in accordance with Wiley Terms and Conditions for SelfArchiving."

The conversion of single-site water oxidation catalysts of type $1^{2+}$ into the more rugged dinuclear derivatives of type $1-\mathbf{d n}^{4+}$ has been studied with time resolved resonance Raman spectroscopy. Key intermediates of the mononuclear and dinuclear water oxidation catalytic cycles have been identified. The electrochemistry of 1-dn ${ }^{4+}$ has been examined in detail showing a strong $\mathrm{pH}$ dependent redox events. The bridging and terminal oxo ligands play a crucial role in the redox properties of the dinuclear catalysts.

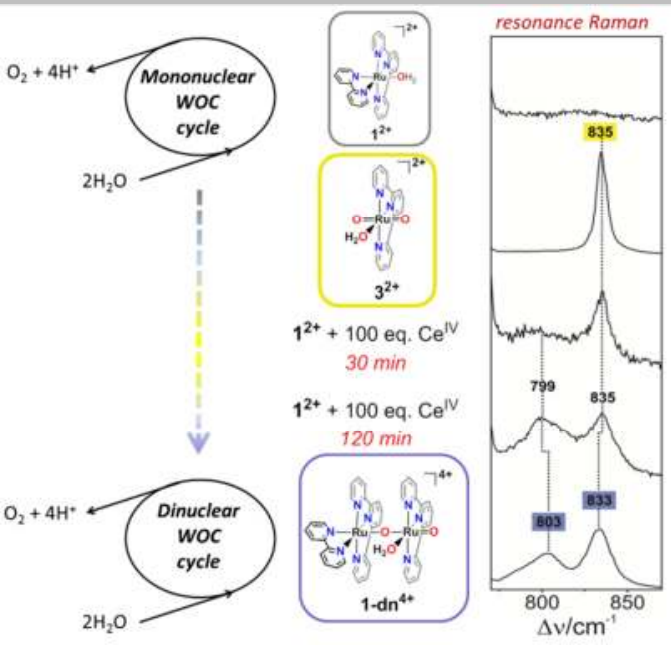

Anke Keidel, Isidoro López, Jana Staffa, Uwe Kuhlmann, Fernando Bozoglian, Carolina GimbertSuriñach, Jordi Benet-Bucholz, Peter Hildebrandt, * and Antoni Llobet*

Page No. - Page No.

Electrochemical and Resonance Raman Spectroscopic Studies of Water-Oxidizing RutheniumTerpyridyl-Bipyridyl Complexes 